\title{
Occupational Accident Patterns and Prevention Measures in Construction Sites in Nairobi County Kenya
}

\author{
Raymond Kemei ${ }^{1}$, Julius Nyerere ${ }^{2}$ \\ ${ }^{1}$ Kenya Army Corps of Engineers, Kenya Defense Forces, Nairobi, Kenya \\ ${ }^{2}$ Department of Management Science and Technology, Technical University of Kenya, Nairobi, Kenya \\ Email address: \\ majkemei@gmail.com (R. Kemei),nyerere.julius@tukenya.ac.ke (J. Nyerere)
}

\section{To cite this article:}

Raymond Kemei, Julius Nyerere. Occupational Accident Patterns and Prevention Measures in Construction Sites in Nairobi County Kenya. American Journal of Civil Engineering. Vol. 4, No. 5, 2016, pp. 254-263. doi: 10.11648/j.ajce.20160405.17

Received: July 31, 2016; Accepted: August 11, 2016; Published: August 29, 2016

\begin{abstract}
Construction accidents don't just happen, they are initiated by unsafe acts, unsafe conditions or both. The construction industry in Kenya plays a vital role in achieving social and economic development goals, providing shelter, infrastructure, and employment. A study was carried out to identify the common accidents in construction sites and to examine the characteristics of the injured and deceased workers and evaluate factors that cause these accidents in Nairobi County, Kenya. The study cross examined data from Directorate of Occupational Safety and Health (DOSH) from Nairobi County ranging from 2010-2014. The study also utilized on-site questionnaires that were administered to 60 contractors in 9 administrative regions in Nairobi County. They constituted all class NCA2 contractors in the county as well as a few NCA3 and NCA4 contractors. Some 41 questionnaires were returned. Accidents were classified by the age of workers, time and month of the accident, location of an accident, causes of accident and management factors affecting the accident. The study established that $65 \%$ of all reported accidents occurred to workers below 37 years old. The accidents peaked between tea break (10am), lunch break (1pm) and after lunch (3pm) and during the months of June and July. The study determined that most construction site injuries were as a result of workers falling from heights (37\%), being hit by falling objects (28\%) and accidents occurring as a result of workers operating equipment $(20 \%)$. Relative Importance (R. I) index of construction hazards were calculated for 24 factors contributing to construction site accidents. The top five hazards identified were: (1) reluctance to provide resources for safety $(0.820)$; (2) lack of staff training $(0.814)$; (3) lack of a safety policy and enforcement of safety regulations (0.795); (4) poor safety consciousness among workers (0.766); and (5) lack of strict operational procedures (0.756) in construction sites. The study concluded that in order to improve safety in the construction industry, each company should have a health and safety policy which is to be implemented in each contract. Furthermore, construction companies need to provide workers with the necessary Personal Protective Equipment (PPE), such as safety belts, retaining belts, safety ropes, and safety harness, and catch nets to prevent workers from being hit by falling materials and to secure them against falling from heights.
\end{abstract}

Keywords: Safety, Occupational Safety and Health (OSH), Construction Sites, Nairobi, Kenya

\section{Introduction}

All over the world, the construction industry has been identified as one of the most hazardous due to its unique nature [1]. Construction sites are also regarded as the most dangerous places to be due to the intensity of work at the given sites. Due to stiff competition in the market, it's common for construction stakeholders, especially those in the lower end of the supply chain to concentrate on completion of the job with minimum time and cost, as a result, causing accidents [2]. An accident is an unplanned, undesirable, unexpected and uncontrolled event [3]. Accidents do not necessarily result in an injury as it can be in terms of damage to equipment and materials. Those accidents that result in injuries or fatalities receive the greatest attention [4]. Fang et al [5] estimate that at least 108,000 workers are killed on construction sites every year, this figure represents about $30 \%$ of all fatal occupational injuries [6].

Construction is one of the world's biggest industries that 
include jobs as diverse as building, civil engineering, demolition, renovation, repair, and maintenance [7]. In Kenya, construction sector contributed 4.9 per cent of the Gross Domestic Product (GDP) in 2014 [8] while in the U.K., it accounted for $10 \%$ and $17 \%$ in Japan in 2013 respectively [6]. The number of people who worked in Kenya's construction industry in 2014 stood at 130,300 and the sector has generated new jobs and grown by $62 \%$ between 2007 and 2013 ahead of other economic sectors [8].

\section{Literature Review}

\subsection{Causes of Accidents in Construction Sites}

"What causes workplace accidents?" has been a question that has been asked across the world, particularly in the construction industry where accident rates are high compared to other industries due to its unique nature [1]. Understanding how accidents occur is important in order to distinguish between factors that are relevant and require action and factors that are unimportant and can be ignored [9].

In an attempt to advance a better understanding of the causes of accidents, many writers have developed accident causation models or theories about how accidents happen. Researchers have divided the theories and models into four generations [10]. The first generation holds a person's traits and unsafe behavior as responsible for accident [11]. Second generation theories (domino theories) conceptualizes a chain of sequential events leading to an accident and call these events as dominos [12]. Removal of any of the domino from the chain will break the chain of accident events. Domino theories are most widely used for accident mitigation in the industry [10]. Deviation theory [13] is a variation of domino theory where possible deviations in each domino are identified and evaluated quantitatively. Injury epidemiology models (originated in the 1960s) represent third generation accident research [14]. Injury epidemiology approach holds that accident prevention efforts do not necessarily lead to accident control in a working system. System approach to accident causation (the fourth generation) emerged in 1970's as a responsible to the challenge of maintaining safety in increasingly complex work system [10]. System approach model highlight the dynamic interaction between organizational and cultural factors in creating the conditions in which a precipitating event can result in a major accident [15]. This approach focuses on energy transfer involved in an injury accident and tries to minimize it in order to minimize the loss [10].

There is a correspondence among the four generations of accident theories, the prevailing accident causation themes, and type of causal factors. Three themes of accident causation: (1) person-as-cause (human factors); (2) system-as-cause (organization/management factors) and (3) system- person sequence as-cause (job-related factors) [16, 17, 18, 19].

Person-as-cause theme holds a person's traits as responsible for accident/injury and examines individualrelated factors for accident causation [10]. First and second generation theories focused on a person as a cause of accidents and when designing interventions. The proponents of the first two generations design behavioral interventions to minimize accidents and injury. The second theme, system-ascause, asserts that the reasons for failure should be traced in the system, rather than holding an individual responsible [20]. System models of the fourth generation support this belief and examines a number of organization-related factors for accident causation [21, 22]. The third theme hypothesizes an interactive sequence between the system and a person. Job-related factors play an important role in determining the nature of system-person interactions.

\subsection{Factors Affecting Injury}

Accident causation theories and causation themes identify several factors contributing towards occurrence of accidents/injuries in work systems. Over several years, a large number of individual-related, job-related, and organizational-related factors are examined in different studies. The problem of safety and accidents in the construction industry is vast and highly complex. Many legislative, sociological, psychological, social, cultural, scientific, technological, organizational, economic, geographic and other factors have a bearing on it. All of these factors should be taken into account in order to create an effective construction project implementation system.

Various combinations of factors and circumstances influence the incidence of occupational accidents. The literature on construction-industry accidents reveals that the factors influencing the incidence of accidents are similar in various countries [23, $24 \& 25]$. Each of the factors is examined individually and presented in brief.

\subsection{Individual-Related Factors}

Individual-related factors are commonly examined by first generation theorists. Age and work experience are mostly investigated. Warr [26] classifies occupational tasks into four types as: age-impaired, age-counteracted, age-neutral and age-enhanced tasks. The relationship of injury risks with age is respectively increasing, inverted U-shaped, unaffected and decreasing for these four tasks [27]. Injury risk is high in initial years of employment, diminishes when an individual acquires sufficient work experience, and rises again with aging [10]. Young workers (under 25 years) are at a higher risk in nonfatal incidents [10] while older workers are at a higher risk in fatal injury [28]. Gun and Ryan [29] find absence of correlation between age/experience and injury. However, such results are exceptions, rather than trends, and are applicable only to age-neutral tasks. Age, experience, education [16] and mental ability correlate well with injury as well with poor work performance [30]. Living habits of workers (alcohol and tobacco consumption) are found to have an association with injury events $\left[\begin{array}{lll}31 & \& & 32\end{array}\right]$. Negative emotional state and lack of emotional stability correlates strongly with injury [33 \& 34]. Skill-based errors correlate strongly with injuries [35 \& 36] as compared to violations 
and mistakes. Absenteeism, risk-taking nature and injuries correlate with each other [37]. Negative affectivity and risktaking behavior along with job dissatisfaction are strong predicators of injury in Indian coalmines [38, 39]. According to Hill and Trist [40], the negative traits (absenteeism, negative affectivity, risky behavior and violations) reflect the quality of relationship of an individual with the organization and contribute to injury.

\subsection{Job-Related Factors}

Job-related factors are predictors of injury [41]. The relationship between job and injury is stronger than individual related factors [42]. Some of the common jobrelated factors examined by researchers and found significant are: occupation [43, 44, 45], location of work [43, 44], hazards in work system [34, 46], activity [44], shift of working [47, 48] and work place factors [49]. Injury risk differs with different occupations e.g. mason, carpenter, bricklayer, plant operator etc. and location of the work. There will be higher chances of getting injured while performing certain activities in a work system. Manual handling of material is one of the commonest activity responsible for strains, sprains and musculoskeletal disorders [50]. Job stress, job dissatisfaction [34], job responsibility [34] and work performance [34] are some of the job related factors that correlate strongly with injury.

\subsection{Organization-Related Factors}

Organization factors have been identified as critical factors in understanding and explaining the work related behaviour of employees in organizations [51]. Some of the significant organizational-related factors are: workgroup size [52], coworker support and supervisory support [53, 54], management commitment to safety [55] and workplace safety status [56].

Higher commitment by management to safety, supervisory support, management perception and investment to safety, smaller working group (less than 15) and training are some of the factors that have been identified with low injury risks. An improvement in perceived safety climate leads to shared understanding of unsafe behaviour [57] which in turn reduces injury risks.

In summary, accidents in construction sites will most likely occur when the following are lacking: certified skilled labor; first aid measures; rigorous enforcement of safety regulations; and organizational commitment to safety. Furthermore, poor maintenance of equipment, poorly educated workers, and inadequate safety consciousness of workers. Also, inadequate personal protective equipment and ineffective operation of safety regulations leave workers predisposed to accidents. Inadequate technical guidance, lack of strict operational procedures, and shortfalls in safety personnel on site contribute to accidents. Finally, poor teamwork, fatigued workers, shortage of safety management manuals, and inadequate flow of information contribute significantly to accidents and associated injuries or fatalities. Table 1 summarises the factors in individual-related, jobrelated and organization related categories.

Table 1. A holistic outline of hazards influencing safety performance in construction sites.

\begin{tabular}{|c|c|c|}
\hline Individual-related factors & Organization-related factors & Job site related factors \\
\hline $\begin{array}{l}\text { - Lack of team spirit } \\
\text { - Poor information flow } \\
\text { - Lack of strict operational procedures } \\
\text { - Poor safety consciousness among workers. } \\
\text { - Fatigue by workers }\end{array}$ & $\begin{array}{l}\text { - Poor safety awareness of project managers } \\
\text { - Reluctance to input resources on safety. } \\
\text { - Lack of organizational commitment. } \\
\text { - Low level of education of workers. } \\
\text { - Shortfall of safety personnel on site. } \\
\text { - Shortage of safety management manuals. } \\
\text { - Lack of experienced project managers } \\
\text { - Lack of innovative technology } \\
\text { - Ineffective operation of safety regulation. } \\
\text { - Poor inspection program } \\
\text { - Lack of training. } \\
\text { - Lack of certified skilled labour } \\
\text { - shortage of safety management manuals }\end{array}$ & $\begin{array}{l}\text { - Lack of personal protective equipment } \\
\text { - Lack of first aid measures } \\
\text { - lack of technical guidance } \\
\text { - Lack of strict operational procedures } \\
\text { - Reckless operation of machines } \\
\text { - Lack of protection of material during storage. } \\
\text { - Lack of protection of material during transportation. } \\
\text { - Ineffective safety regulation } \\
\text { - -Poor maintenance of equipment }\end{array}$ \\
\hline
\end{tabular}

This study was designed to fill in the gap in literature for researchers, safety professionals and policy makers in government who will like to understand the characteristics of construction accidents in Nairobi County, Kenya.

The aim of this study was to analyse occupational construction accidents between 2010 and 2014 in Nairobi County. The objectives are to (1) examine the characteristics of the injured and deceased workers; (2) determine the common construction site accidents in the study area; (3) establish the management factors causing construction site accidents in the study area.

\section{Research Methodology}

The research adopted a mixed method approach in pursuing the objectives. It was noted in part, that a multiple world view presented the researchers with a better understanding of the issues raised in relation to occupational, health and safety within the study's setting. Information required to shed light on Occupational, health and safety in construction industry with respect to the research objectives, necessitated the adoption of both quantitative and qualitative/historical research techniques. The mixed method 
approach involves collecting both numeric and text information, either simultaneously or sequentially, so as to best understand research problems, with the final database representing both quantitative and qualitative information [58].

This research is confined to safety in building construction sites in Nairobi County and will not focus on road, mining or any or any other forms of construction currently taking place. The targeted building construction projects belonged to both private sector and the government projects. The study targeted projects which have been registered their projects with National Construction Authority (NCA) and Directorate of Occupational safety and Health (DOSH) thus limiting to the major contractors between NCA1 to NCA4. Most minor contractors below NCA5 don't adhere with the full registration expected by NCA and DOSH and were not covered in this study. The study area targeted Nairobi County building construction sites due to the growth in construction industry in Nairobi relative to other towns in Kenya.

The researchers approached DOSH on the need to undertake the study. Kenya is governed by Occupational Safety and Health Act which was enacted in 2007. The source of the archival data was from all reported accidents at DOSH office and data recorded in occupational accident/disease of employee form (DOSH 1 form). It was established that prior to 2010 the data cannot be retrieved since a proper database and management system was established in mid-2009. Thus the study analyses all the accidents reported between January 2010 and December 2014.

According to Kenya National Bureau of Statistics (KNBS) Economic Survey for FY 2013/2014, there was an increase in housing by $34.2 \%$ from Kshs 181.1 Billion in 2012 to Kshs 243.1 Billion in 2013 and Nairobi County accounted for $41.1 \%$ to stand at Kshs 190.6 Billion in 2013 and annual shortfall of housing units of 200,000 . This is attributed to the rapid growth of population in Nairobi.

A questionnaire was also designed with a holistic outline of hazards influencing safety performance in construction sites (as summarized in Table 1). The objective was to establish factors causing construction site accidents in the study area. Two main sections was of the questionnaire was designed, the first section included general information, such as details of the construction company under study, the number of years of existence, specialization, and number of employees. The questionnaire also captured details about the professional body the company is registered with, the company classification (NCA1 [large] to NCA4 [medium]) and the approximate value of the contract currently being undertaken.

The second section of the questionnaire evaluated the health and safety procedures adopted by the company. The questionnaire captured data on the number of accidents in each construction site for the last three years, common construction site accidents, health and safety budgets, and the causes of construction site accidents.

\subsection{Administration of Questionnaires}

Nine administrative regions of Nairobi County were used as a sampling frame, these are; Central Business District (CBD), Dagoreti, Embakasi, Kasarani, Kibera, Makadara, Pumwani, Langata and Westlands. Respondents were asked to rate the extent to which 25 management variables influenced site safety performance in the ongoing projects.

Questionnaires were distributed to construction sites of ongoing projects in Nairobi County. The response rate was noted to be $68 \%$. Companies involved in the study were registered with Building and Civil Engineering contractors in Kenya and Kenya Property Developers Association. Some 36 of the returned questionnaires were from NCA1 contractors, 2 were from NCA2 contractors, 2 were from NCA3 contractors and 1 was from an NCA4 contractor. Respondents were individuals who were experienced in construction and were classified by the National Construction Authority (NCA)

\subsection{Measurement of the Importance of Accident Factors}

The study further established the relative importance of twenty five (25) factors identified contributing significantly towards construction site accidents (Table 1) using Likert Scale 1 and 5. A scale of 1 indicated that, the factor is 'not important and all' and 5 is 'very important'

Furthermore, Statistical analysis was conducted using the Statistical Package for Social Science (SPSS). To determine relative ranking of the factors above, the scores were transformed to relative indices [57]

Relative Importance (\%) of factor expressed as;

$$
R I=\frac{W}{A^{*} N}
$$

Where

$\mathrm{W}=$ Weight given to each factor by respondents.

$\mathrm{A}=$ Highest Weight.

$\mathrm{N}=$ Total number of respondents concerning that factor.

\section{Results and Analysis}

\subsection{Characteristics of the Injured and Deceased Workers}

Gender

Out of all the 237 workers who reported construction accidents during the period running 2010-2014, 236 (99.6\%) were male and $1(0.4 \%)$ was a female. This is not surprising as construction industry is male dominated and research undertaken in Singapore on construction fatalities between June 2006 - May 2008 showed that $100 \%$ of the deceased workers were male [58]. Previous studies suggested that that male workers were represented heavily in severe and fatal accidents than female workers and injuries to female workers were mild and moderate consequences [59, 60, 61, 62]. This pattern was believed to be reflection of the differences in tasks undertaken by male and female workers on construction sites. 
Table 2. Characteristics of construction accidents between Jan 2010 - Dec 2014.

\begin{tabular}{|c|c|c|c|c|c|}
\hline Factor & No & $\%$ & Factor & No & $\%$ \\
\hline Age & & & Skill area & & \\
\hline $18-27$ & 63 & 26.6 & Casual & 84 & 35.4 \\
\hline $28-37$ & 90 & 38.0 & Mason & 51 & 21.5 \\
\hline $38-47$ & 59 & 24.9 & Machine Operator & 40 & 16.9 \\
\hline $48-57$ & 22 & 9.3 & Carpenter & 28 & 11.8 \\
\hline $58-68$ & 3 & 1.3 & Supervisor & 16 & 6.8 \\
\hline Month & & & Mechanic & 5 & 2.1 \\
\hline January & 20 & 8.4 & Guard & 3 & 1.3 \\
\hline February & 15 & 6.3 & Welder & 3 & 1.3 \\
\hline March & 20 & 8.4 & Steel Fixer & 3 & 1.3 \\
\hline April & 21 & 8.9 & Electrician & 2 & 0.8 \\
\hline May & 16 & 6.8 & Painter & 1 & 0.4 \\
\hline June & 25 & 10.5 & Plumber & 1 & 0.4 \\
\hline July & 36 & 15.2 & Administrative area & & \\
\hline August & 20 & 8.4 & Kasarani & 56 & 23.6 \\
\hline September & 20 & 8.4 & Embakasi & 43 & 18.1 \\
\hline October & 18 & 7.6 & Westlands & 43 & 18.1 \\
\hline November & 17 & 7.2 & Kibera & 34 & 14.3 \\
\hline December & 9 & 3.8 & Nairobi Central & 20 & 8.4 \\
\hline Time & & & Makadara & 15 & 6.3 \\
\hline$<7: 59$ am & 2 & 0.8 & Pumwani & 13 & 5.5 \\
\hline 8:00 am - 8:59 am & 11 & 4.6 & Dagoreti & 11 & 4.6 \\
\hline 9:00 am - 9:59 am & 22 & 9.3 & Langata & 2 & 0.8 \\
\hline $10: 00 \mathrm{am}-10: 59 \mathrm{am}$ & 35 & 14.8 & Gender & & \\
\hline $11: 00 \mathrm{am}-11: 59 \mathrm{am}$ & 24 & 10.1 & Female & 1 & 0.4 \\
\hline 12:00 noon - $12: 59 \mathrm{pm}$ & 30 & 12.7 & Male & 236 & 99.6 \\
\hline $1: 00 \mathrm{pm}-1: 59 \mathrm{pm}$ & 8 & 3.4 & & & \\
\hline 2:00 pm - 2: $59 \mathrm{pm}$ & 25 & 10.5 & & & \\
\hline 3:00 pm - 3:59 pm & 34 & 14.3 & & & \\
\hline 4:00 pm - 4:59 pm & 28 & 11.8 & & & \\
\hline 5:00 pm - 5:59 pm & 12 & 5.1 & & & \\
\hline$>6: 00 \mathrm{pm}$ & 6 & 2.5 & & & \\
\hline
\end{tabular}

\subsection{Age}

The age distribution is shown in Table 2 . About $65 \%$ of all accidents reported happened to those below 37 years old. The workers in this age group are young, relatively inexperienced and may not identify the hazards. Those above 48 years have the lowest incidence of accidents $(10.6 \%)$. They are more mature and experienced, more likely married and have children going to school and are less likely to expose themselves to unnecessary hazards.

It has been reported in many studies that an increase in age of the worker is positively correlated with the degree of accident severity suffered [59, 61]. Moreover, Cheng et al [60] argued that older workers (workers aged above 45) were involved only in few accidents compared to young and middle aged workers, but their sufferings were much severe, including fatalities, specifically for workers aged over 60 .

Research conducted in Iran between 2008 - 2012 showed that $69 \%$ of occupational accidents occurred to workers who are below 35 years [63]. In the US, the age of 35-44 has the highest fatality rates of $24.8 \%$ according to research conducted by Florence et al [58]. US experts believe that training both older and younger workers is important to reduce construction accidents [58].

In US, it is a requirement that all workers must be trained: (1) before they start working, (2) every year, (3) before being assigned to a job that requires new skills and (4) after deficiency is detected [58]. It's recommended that there is need to have a competent safety officer on construction site that will be able to identify safety risks, check safety equipment and remind the workers on safety matters constantly.

\subsection{Month of Accidents}

Kenya's financial year starts in July and ends in June. From figure 1, it's apparent that most of construction site accidents occur towards the end of the financial year in June $(10.5 \%)$ and July $(15.2 \%)$. It is common for construction stakeholders to concentrate exclusively on completing projects with minimum time and cost. Safety is therefore not 
regarded much. Towards the end of financial year, multiple activities will be carried out simultaneously and site supervisors will normally be stretched which may have led to accidents. Construction stakeholders will try and complete the projects so that they can get paid.

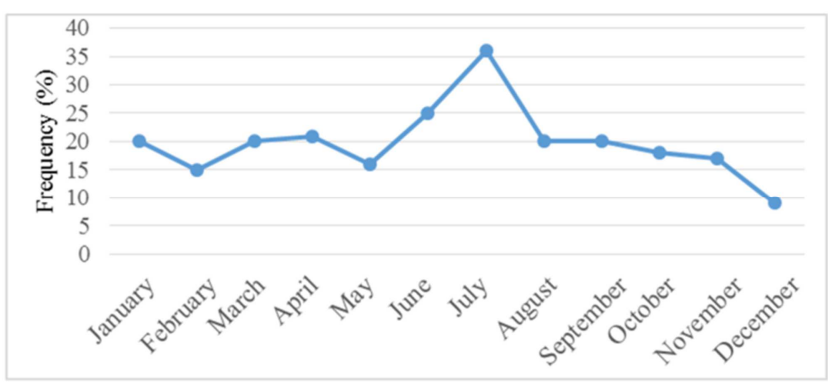

Figure 1. Month of occurrence of construction accidents between Jan 2010 Dec 2014.

To avoid rushing to complete the projects in June, It's recommended that clients could help by not specifying completion dates in May so that there will be no need to rush to complete the work in June. Better scheduling need to be done with increased checks on site from April. Experts in US recommend that safety meeting before starting work is effective and is highly recommended [58].

\subsection{Time of the Accident}

Construction work is normally carried out from 8 am to 6 pm in a typical day in Nairobi County, breaks are taken at around $10 \mathrm{am}$ and lunch break from $1 \mathrm{pm}$.

The pattern of accident occurrence is shown in Figure 2 and the pattern shows many accidents occur just before tea break (14.8\%), lunch break (12.7\%) and after lunch (14.3\%). Research undertaken in Iran showed that $44.97 \%$ of accidents occurred between $9 \mathrm{am}$ and $1 \mathrm{pm}$ which is a similar trend to Nairobi County, Kenya [63].

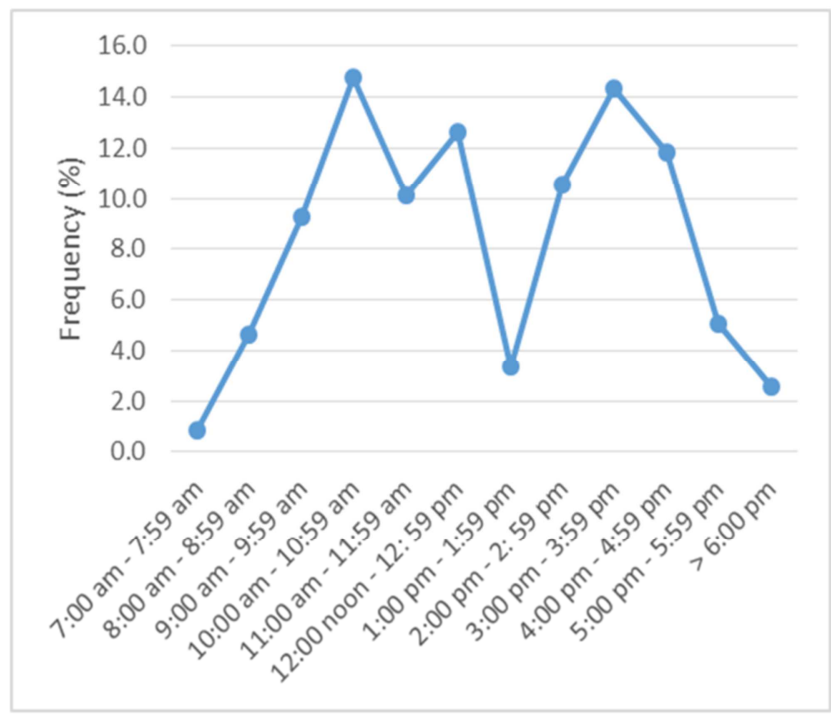

Figure 2. Time of occurrence of construction accidents between 7 am to $6 \mathrm{pm}$.

Safety appears to be compromised around rest times leading to accidents. The probable reason is that workers push themselves to complete the work before the break or are pressured by supervisors to finish their work before break time. Rushing through a job may cause the workers to make mistakes and an accident will occur [58]. The second reason is that before a scheduled rest, workers are physically tired causing them to loose concentration. The workers could be having physical fatigue and high mental pressure. Its recommended that supervisors should allow flexible rest time and scheduled inspections should be done 30 minutes before and after workers' break.

\subsection{Administrative Area in Which the Accident Occurred}

The location of the sites in which the accident occurred was also investigated and the results are shown in Table 3.

Table 3. Location of Accident Occurrence.

\begin{tabular}{lll}
\hline Division & Frequency & Frequency (\%) \\
\hline Kasarani & 58 & 24.9 \\
Embakasi & 42 & 18 \\
Westlands & 41 & 17.6 \\
Kibera & 32 & 13.7 \\
Nairobi Central & 21 & 9 \\
Makadara & 14 & 6 \\
Pumwani & 13 & 5.6 \\
Dagoreti & 12 & 5.2 \\
\hline
\end{tabular}

The pattern shows that more accidents occurred in Kasarani, Embakasi, Westlands and Kibera divisions. It's worth noting that Kasarani is the furthest from the Central Business District (CBD). Various researchers have identified the link between accident severity and project location. Ling et al [58] reported that high-rise construction in CBD areas recorded a high number of fatal accidents. Dumrack et al [64] noted that projects located in the CBD and outer suburbs further from the $\mathrm{CBD}$, represented largely fatal accidents than those on inner suburbs.

Inadequate staffing compared with increased workload has continued to affect the occupational safety monitoring. Work Injury Benefits processing take a lot of officers and support staff time leaving them with little space to perform other official duties as specified in their performance contracts [65]. During 2010-11 staffing levels in DOSH indicate that only $36 \%$ of staff required were employed translating to 51 technical officers and 21 specialists against a working population of 10.3 million for the whole country [65]. This has been largely attributed to the inability of the Directorate of Occupational Safety and Health Services, as a department to attract and retain qualified personnel.

Non-availability of transport for field stations remained a major challenge for DOSH [65]. This seriously affected the performance of the stations since officers were forced to concentrate their inspections to within walking distances or borrow transport elsewhere which was unreliable.

It's recommended that the government procures official vehicles for safety officers so that they can cover all areas falling under them. Further, the government needs to increase staffing levels within DOSH. 


\subsection{Construction Site Accidents in Nairobi County}

In the 237 construction sites accidents studied the five most common types of accidents include falling from height (36.7\%), being hit by falling materials $(27.8 \%)$, injury from operating machines $(20.3 \%)$ and other forms of accidents $(14.8 \%)$ (Table 4$)$. The most significant causes of accidents in construction sites in China and the USA to include falling from heights $(37-50 \%)$, electrocution (5-13\%), hit by falling objects (12-21\%), collapse of earthwork in China $(9 \%)$ and injuries due to use of heavy machine in China (9\%) [66], [67].

Table 4. Construction site accidents between Jan 2010 - Dec 2014.

\begin{tabular}{ll|l}
\hline Reason For Accident & Frequency & $\mathbf{\%}$ \\
\hline Falling from Height & 87 & 36.7 \\
Falling Object (s) & 66 & 27.8 \\
Operating a machine & 48 & 20.3 \\
Other form of accident & 35 & 14.8 \\
Electric shock & 1 & 0.4 \\
TOTAL & 237 & 100 \\
\hline
\end{tabular}

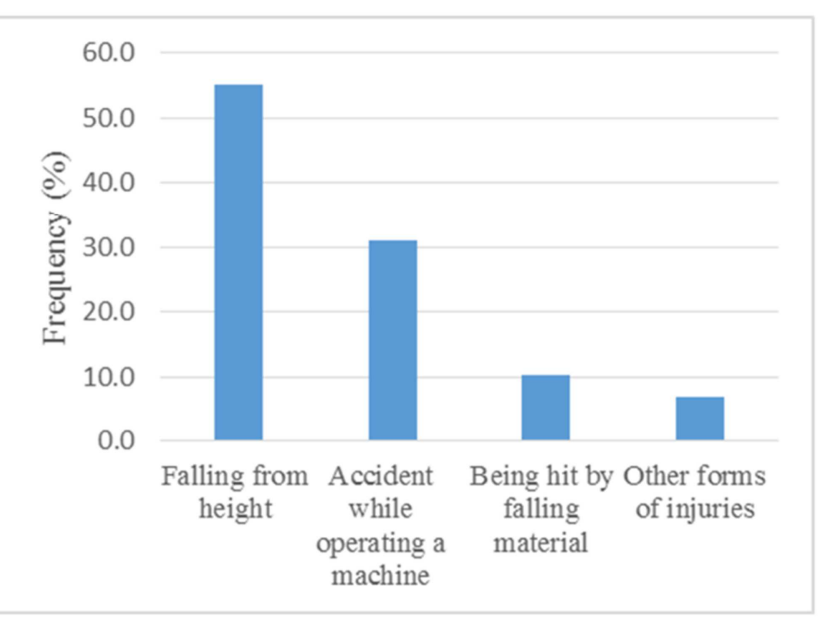

Figure 3. Reason for Fatality Occurrence.

Most construction site accidents in South Africa occur as a result of falling from heights $(28.18 \%)$, being hit by falling objects (22.85\%), electrocution (19.57\%), and injuries caused by motor operated machines such as motor vehicles and concrete mixers (18.51\%) [68].

Further, data from the analysis shows that high rate of accidents are among unskilled workers (35.4\%). Other than unskilled workers, the other three occupations with the highest injury numbers were: Masons (21.5\%), machine operators $(16.9 \%)$ and carpenters $(11.8 \%)$. Third party accidents also occurred to site supervisors $(6.8 \%)$. Since unskilled workers have tasks everywhere, they are exposed to every type of accident. Most of the accidents for masons and carpenters are due to falling from height and being hit by falling objects.

It may be concluded that falling from heights contribute and being hit by falling objects and about $65 \%$ of all construction site accidents (Table 3 ). Therefore, construction companies need to provide workers with the necessary Personal Protective Equipment (PPE), which include safety belts, retaining belts, safety ropes, and safety harness and catch nets to prevent being hit by falling materials and falling from heights. Furthermore, workers need to be continuously trained on the importance of using PPE.

\subsection{Management Factors Contributing to Construction Site Accidents in Nairobi County}

The ten most significant factors affecting safety in construction sites (Table 5) include Reluctance to invest in safety (0.820); lack of training (0.814); lack of enforcement of safety regulation ( 0.795$)$; poor safety consciousness of workers (0.766); lack of strict operational procedures (0.756); lack of personal protective equipment (0.732); poor safety awareness from top leaders (0.693); reckless operation of machines (0.698); and shortfall of safety personnel (0.668).

The study showed that $61 \%$ of the construction sites surveyed had a project value of over KES 500 Million (approx. 5 Million USD). However, only 4\% budgeted for over KES 2 Million (approx. 20,000 USD) for health and safety as shown in Figure 4. This confirms that management does not prioritize health and safety during the project cycle leading to construction accidents.

Effective safety training reduces the number of construction site accidents [69]. Our data shows that lack of training in health and safety was $2^{\text {nd }}$ with R.I of 0.814 . In Kenya, provision of health and safety education in construction related university degrees is poor. A need arises therefore for designers, architects, site personnel and suppliers to be trained to raise their awareness on construction sites risks.

Project managers have a safety responsibility to prepare project safety plan, identify potential hazards at the site, prepare a written safety plan and insist on reporting of injuries, death and property damage as a result of accidents [70]. In this study, $12 \%$ of the construction sites visited lacked a written safety policy to ensure safety in construction site.

Table 5. Relative Importance of Construction site Hazards between Jan 2010 - Dec 2014.

\begin{tabular}{llc}
\hline CONSTRUCTION SITE HAZARD & Relative Importance & Rank \\
\hline Individual Related factors & & \\
Poor safety consciousness of workers & 0.765854 & 5 \\
Lack of strict operational procedure & 0.756098 & 18 \\
Lack of teamwork spirit & 0.580488 & 20 \\
Poor information flow & 0.531707 & 21 \\
Fatigue by workers & 0.468293 & \\
Organization related factors & & \\
\hline
\end{tabular}




\begin{tabular}{lll}
\hline CONSTRUCTION SITE HAZARD & Relative Importance & Rank \\
\hline Reluctance to input resources on safety & 0.819512 & 2 \\
Lack of training & 0.814634 & 3 \\
Lack of rigorous enforcement of safety regulation & 0.795122 & 6 \\
Poor safety awareness from top leaders & 0.741463415 & 8 \\
Lack of organizational commitment & 0.702439 & 10 \\
Shortfall of safety personnel on site & 0.668293 & 13 \\
Lack of experienced project managers & 0.658537 & 11 \\
Ineffective operation of safety regulation & 0.658537 & 14 \\
Lack of certified skilled labor & 0.642702 & 15 \\
Low level of education of workers & 0.60000 & 19 \\
Lack of innovative technology on safety measures & 0.560976 & 22 \\
Shortage of safety management manuals & 0.429268293 & 7 \\
Job-site related factors & & 9 \\
Lack of personal protective equipment & 0.731707 & 12 \\
Reckless operation of machines & 0.697561 & 16 \\
Lack of technical guidance & 0.658536585 & 17 \\
Poor maintenance of equipment & 0.595122 & 23 \\
Lack of first aid measures & 0.585365854 & 24 \\
Lack of protection of material during transportation & 0.419512 & 0.365854 \\
Lack of protection of material during storage & & \\
\hline
\end{tabular}

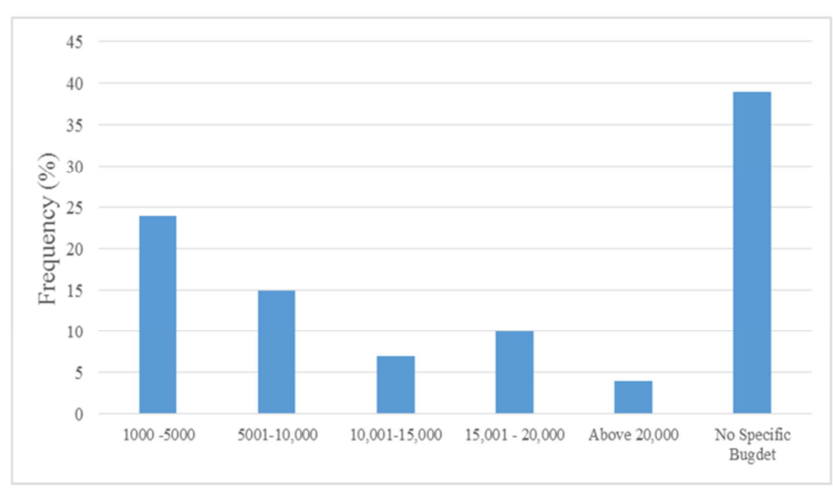

Figure 4. Investment in Health and Safety (USD).

\section{Conclusion}

The study was based on 237 reported construction site accidents in Nairobi County over a period of 4 years. The following are the main findings of this study:

- Most of the workers who were injured or killed when accidents occurred in construction sites were below 37 years old.

- Many accidents occurred in June and July during the closure of financial year.

- Safety was mostly compromised around rest times and accidents occurred before tea and lunch break and immediately after lunch.

- Safety monitoring of construction sites is not undertaken by DOSH personnel due to low staffing level and inadequate transport.

- Falling from height and being hit by falling objects contributes towards about $64 \%$ of all construction site accidents.

- Majority of the construction companies allocate less than $1 \%$ of the project budget to health and safety. This could be because the construction industry does not seem to have a clear policy on accident prevention.

The findings suggest that compared to developed countries, Kenya still has a high number of construction site accidents. With the aid of historical data on accidents, safety professionals should identify the hazards on their specific construction sites and plan for the best methods for eliminating or controlling the hazards.

\section{Recommendations}

Based on the study, the following are key recommendations that can help improve safety performance in construction projects.

- Construction sites must have safety officers to identify project risks.

- Construction companies need to provide funding for health and safety and provide workers with the necessary Personal Protective Equipment (PPE).

- All employees from top management should undergo proper job related health and safety training. This can be done through customized or tailor made courses, workshops, seminars, conferences or field demonstrations.

- In order to improve safety in the construction industry, health and safety should be included right from preparation of contract documents.

- Directorate of Occupational Safety and Health (DOSH) to be facilitated by government so that they can effectively monitor occupational safety in construction sites.

- Clients should not be specifying completion dates of projects in May so that there will be no need to rush to complete the work in June. Better scheduling need to be done with increased checks and site visits from April.

\section{References}

[1] Jannadi, O. A., Bu-Khamsin, M. S., (2002). Safety factors considered by industrial contractors in Saudi Arabia. Building and Environment Journal 37 (5), 539-547. 
[2] Thomas, N. S., Kam, P. C. and Martin, R. S. (2004). A framework for evaluating the safety performance of construction contractors. Building and Environment Journal $40(5), 347-355$.

[3] Abdul, R. A. H., Muhd, Z. A. M. and Bachan, S. (2008). Causes of accidents at construction sites. Malaysian Journal of Civil Engineering 20 (2): 242-259.

[4] Hinze, J., Huang, X. and Terry, L., (2005). The Nature of Struck-by Accidents. Journal of Construction Engineering and Management, 131 (2), pp. 262.

[5] Fang, D. P., Huang, X. Y. and Hinze, J. (2004). Benchmarking studies on construction safety management in China. Journal of Construction Engineering and Management, 130 (2), 424-432.

[6] Gurcanli, G. E. and Mungen, U. (2013). Analysis of construction accidents in Turkey and responsible parties (2013). Journal of Industrial Health, 51, 581-595.

[7] Hallowell, M. R. (2011). Safety knowledge management in American Construction Organisations. Journal of Construction Engineering and Management, 28, 203-211.

[8] Kenya National Bureau Statistics (2014), Facts and Figures Report 2014.

[9] Swuste, P. (2008) "You will only see it, if you understand it" or occupational risk prevention from a management perspective. Human Factors and Ergonomics in Manufacturing, 18, 438453.

[10] Vivek, V. K., Maiti, J. and Ray, P. K. (2012). Occupational injury and accident research: A comprehensive review. Safety Science 50 (12) 355-367.

[11] Greenwood, M. and Wood, H. (1919). The incidence of industrial accidents upon individuals with special reference to multiple accidents. Industrial Fatigue Research Board, London.

[12] Heinrich, H. W. (1932). Industrial Accident Prevention. New York: McGraw-Hill.

[13] Kjellen, U. (1984). An evaluation of safety information systems at six medium sized and large firms. Journal of Occupational accidents 3 273-288.

[14] Haddon, W., Suchman, E. and Klein, D. (1964). Accident Research: Methods and Approaches. Harper \& ROW, New York.

[15] Gibb, A. G. F., Lingard, H., Behm, M. and Cooke, T. (2014). Construction accident casualty: Learning from different countries and different consequences. Journal of Construction Management and Economics 32 (5) 446-459.

[16] Leigh, J., Mulder, H., Want, G., Farnsworth, N. and Morgan, G. (1990). Person and environmental factors in coal mining accidents. Journal of Occupational Accidents, 13, 233-250.

[17] Brown, K., Willis, P. and Prussia, G. (2000). Predicting safe employee behavior in the steel industry: development and test of a sociotechnical model. Journal of Occupational Management, 18, 445-465.

[18] Paul, P and Maiti, J. (2007). The role of behavioral factors on safety management in underground mines. Safety Science 45, 449-471.

[19] Paul, P and Maiti, J. (2008). The synergic role of sociotechnical and personal characteristics on work injuries in mines. Ergonomics, 51, 737-767.
[20] Deming, W. (1986). Out of Crisis. MIT Centre for Advanced Engineering Study, Cambridge.

[21] Reason, J. (1997). Managing the Risks of Organizational Accidents. Andershot, UK.

[22] Zohar, D. (2010). Thirty years of Safety Climate research: reflections and future directions. Accident Analysis and Prevention 42, 1517-1522.

[23] Tam, C. M., Zeng, S. X. and Deng, Z. M., (2004). Identifying elements of poor construction safety management in China. Safety Science 42: 569-586.

[24] Macedo, A. C. and Silva I. L., (2005). Analysis of occupational accidents in Portugal between 1992 and 2001 Safety Science 43: 269-286.

[25] Aksorn, T. and Hadikusumo, B. H. W., (2008) Critical success factors influencing safety program performance in Thai construction projects. Safety Science 46: 709-727.

[26] Warr, P. (1993). In what circumstances does job performance vary with age? European Work and Organization Psychologist, 3, 237-249.

[27] Laamme, L., Menckel, E., (1995). Aging and occupational accidents: a review of the literature of the last three decades. Safety Science 21, 145-161.

[28] Salminen, S. (2004). Have young workers more injuries than old ones? An international literature review. Journal of Safety Research, 35, 513-521.

[29] Gun, R. and Ryan, C. (1994). A case-control of possible risk factors in the causation of occupational injury. Safety Science, $16,47-66$

[30] Ferguson, J., McNally, M. and Booth, R. (1984). Individual characteristics as predictors of accidental injuries in naval personnel. Accident Analysis and Prevention 16, 55-62.

[31] Dawson, D. (1984). Heavy drinking and the risk of occupational injury. Accident analysis and prevention, 26, 655-665.

[32] Zwerling, C., Sprince, N., Wallace, R., Davis, C., Whitten, P and Heering, S. (1996). Alcohol and occupational injuries among older workers. Accident analysis and prevention, 28, 655-665.

[33] Verhaegen, P., Strubble, J., Vonck, R. and Van den Abeele, J. (1985). Absenteeism, accidents and risk taking. Journal of occupational Accidents, 7, 177-186.

[34] Maiti, J., Bhattacherjee, A. and Bangdiwala, S. (2004). Loglinear model for analysis of cross-tabulated coal mine injury data. Injury Control and Safety Promotion 8, 229-236.

[35] Reason, J. (1990). Human error. Cambridge University Press.

[36] Hobbs, A. and Williamson, A. (2002). Unsafe acts and unsafe outcomes in aircraft maintenance. Ergonomics 45, 866-882.

[37] Verhaegen, P., Vanhalst, B., Derijckle, H. and Hoecke, M. V. (1976). The value of some psychological theories on industrial accidents. Journal of occupational Accidents, 1, 39-45.

[38] Paul, P., Maiti, J., Dasgupta, S. and Forjuoh, S. (2005). An epidemiological study of injury in mines: implications for safety promotions. Injury control and safety Promotion, 12, 157-165. 
[39] Paul, P and Maiti, J. (2007). The role of behavioral factors on Safety management in underground mines. Safety Science 45, 449-471.

[40] Hill, J. and Trist, E. (1953). A consideration of industrial accidents as a means of withdrawal from the work situation- a study of their relation to other absences in an iron and steel works. Human relations, 6, 357-380.

[41] Ferguson, J., McNally, M. and Booth, R. (1985). Accident injuries among naval personnel by occupation, duty status and pay grade. Accident Analysis and Prevention 17, 79-86.

[42] McLeod, R., Stockwell, T. Rooney, R., Stevens, M., Philips, M. and Jelinek, G. (2003). The influence of extrinsic and intrinsic risk factors on the probability of sustaining an injury. Accident Analysis and Prevention 35, 71-80.

[43] Leigh, J., Mulder, H., Want, G., Farnsworth, N. and Morgan, G. (1990). Personal and environmental factors in coal mining accidents. Journal of occupational Accidents 13, 233-250.

[44] Maiti, J. and Bhattacherjee, A. (1999). Evaluation of risk of occupational injuries among underground coal mine workers through multinomial logit analysis. Journal of Safety Research 30, 93-101.

[45] Khanzode, V., Maiti, J. and Ray, P. (2011). A methodology for evaluating and monitoring of recurring hazards in underground coal mines. Safety Science 49, 1172-1179.

[46] Levin, L., Oler, J. and Whiteside, J (1985). Injury incident rates in a paint company on rotating production shifts, Accident Analysis and Prevention, 17, 67-73.

[47] Frank, A. (2000). Injuries related to shift work. American Journal of preventive medicine, 18, 33-36.

[48] Haslam, R., Hide, S., Gibb, A., Gyi, D., Pavitt, T., Atkinson, S. and Duff, A. (2005). Contributiong factors in construction accidents. Applied Ergonomics 36, 401-415.

[49] Davies, J., Kemp, G., Frostick, S. and McElwaine, C. D. J. (2003). Manual handling injuries and long term disability. Safety Science 41, 611-625.

[50] Paul, P and Maiti, J. (2005). Development and test of sociotechnical model for accident/injury occurrence in underground coalmines. The South African Institute of mining and metallurgy 105, 1-12.

[51] Bakshi, A., Kumar, K., Rani, Ekta. (2009). Organisational Justice Perceptions as Predictor of Job Satisfaction and Organisation Commitment. Journal of International Business and Management, 4 (9), 145-154.

[52] Guastello, D. and Guastello, S. (1987). The relationship between work group size and occupational accidents. Journal of Occupational Accidents 9, 1-9.

[53] Gillen, M., Baltz, D., Gassel, M., Kirsch, L. and Vaccaro, D. (2002). Perceived safety climate, job demands and coworker support among union and nonunion injured construction workers. Journal of Safety Research 33, 33-51.

[54] O'Toole, M., (2002). The Relationship between Employees' Perceptions of Safety and Organizational Culture. Journal of Safety Research, 33, 231-243.

[55] Lindell, M. (1997). Occupational health inspection scores predict rates of workers lost time injuries. Accident Analysis and Prevention 29, 563-571.
[56] Prussia, G., Brown, K. and Willis, G. (2003). Mental models of safety: do managers and employees see eye to eye? Journal of Safety Research 34, 134-156.

[57] Creswell, J. W. (2003). Research Design: Qualitative, Quantitative, and Mixed Methods Approaches (2 ${ }^{\text {nd }}$ ed.). California: Sage Publications.

[58] Tam C. M., Zeng S. X. and Deng Z. M. and Ho C. S. (2000). Quest for continuous quality improvement for public housing construction in Hong Kong. Construction Management and Economics Journal 18 (4): 437-446.

[59] Ling, F. Y., Liu, M. and Woo, Y. W (2009). Construction fatalities in Singapore. International journal of Project Management 27: 717-726.

[60] Dumrak, J., Mostafa, S., Kamardeen, I. and Rameezdeen, R. (2013). Factors associated with the severity of construction accidents: the case of south Australia. Australasian Journal of Construction Economics and Building, 13 (4), 32-49.

[61] Cheng, C. W., Leu, S. S., Cheng, Y. M., Wu, T. C. and Lin, C. C. (2012). Applying data mining techniques to explore factors contributing to occupational injuries in Taiwan's construction industry. Accident analysis and prevention, 48, 214-22.

[62] López, M. A. C., Ritzel, D. O., Fontaneda, I. and González Alcantara, O. J. (2008). Construction industry accidents in Spain. Journal of safety research, 39 (5), 497-507.

[63] Hinze, J., Huang, X. and Terry, L. (2005). The nature of struck-by accidents. Journal of Construction Engineering Management, 131 (2), 262-68.

[64] Alizadeh, S. S., Mortazavi, S. B. and Sepehri, M. M., Ling, (2015). Analysis of Occupational Accident Fatalities and Injuries among Male Group in Iran between 2008 and 2012. Iran Red Cresent Med Journal 17 (10): e18976

[65] Dumrak, J., Mostafa, S., Kamardeen, I. and Rameezdeen, R. (2013). Factors associated with the severity of construction accidents: the case of south Australia. Australasian Journal of Construction Economics and Building, 13 (4), 32-49.

[66] Directorate of Occupational Health and Safety Services (DOHSS), (2011). Kenya Annual Report for 2011.

[67] Suazo, G. A. and Jaselskis E. J. (1993). Comparison of construction codes in United States and Honduras, Journal of Construction Engineering and Management 119 (3): 560-572.

[68] Koehn, R. K. and Pan C (1995). Safety in developing countries, professional and bureaucratic problems. Journal of Construction Engineering and Management, 121 (3): 261265.

[69] Smallwood. J., T. Haupt and W. Shakantu (2013). Health and Safety in South Africa. Published by construction industry development Board of South Africa

[70] Loosemore, M. and Lee P. (2001). Communication problems with ethnic minorities in construction industry. International Journal of Project Management 20: 517-524.

[71] Tam C. M., Zeng S. X. and Deng Z. M. and Ho C. S. (2000). Quest for continuous quality improvement for public housing construction in Hong Kong. Construction Management and Economics Journal 18 (4): 437-446. 